\title{
IMPLEMENTING GOVERNMENT POLICY IN SUPPLY CHAINS: AN INTERNATIONAL COPRODUCTION STUDY OF PUBLIC PROCUREMENT
}

Cite as: Harland, C., Telgen, J., Callender, G., Grimm, R., \& Patrucco, A. (2019).

Implementing government policy in supply chains: an international coproduction study of public procurement. Journal of supply chain management, 55(2), 6-25.

\begin{abstract}
Public procurement is the commercial arm of governments, contracting for goods and services to feed public sector service provision. However, mainstream operations and supply chain management journals have published little on supply chains to governments, public procurement, and the significance of engaging small businesses in government supply chains. Policy feedback theory and thirteen coproduced international case studies of public procurement and small-business agency dyadic relationships are used to explore this space. The research highlights the importance of both public procurement and small business as areas of policy and supply chain management research. Policy feedback theory is introduced as a means to understand relationships, and is applied to a coproduction study to understand how supply chain management research can both explore and change policy.
\end{abstract}

Keywords: Contracting, procurement processes, case studies, engaged methods

\section{INTRODUCTION}

Despite public-sector spending representing up to 57\% of nations' GDPs (OECD 2017), there has been little research attention paid to the economic importance of supply chains to governments. There is research evidence of how, in the private sector, purchasing can influence 
supply chain behaviour to deliver firms' policies, notably relating to environmental sustainability policies (Rao, 2002; Klassen \& Vachon, 2003; Hall \& Matos, 2010; Sarkis, 2012; Walker \& Jones, 2012; Hafezalkotob, 2015). But far less is published in operations and supply chain management journals about public sector suppliers and their associated government policies (Amann et al., 2014).

Small businesses are important to economies, society and larger businesses globally. For instance, according to reports published by the US Small Business Administration they represent $99.7 \%$ of all employer firms, employ over half of all private sector employees, pay $44 \%$ of the total US private payroll, have generated $64 \%$ of net new jobs over the past 15 years, create more than half of non-agricultural GDP, hire $40 \%$ of high tech workers, make up $97.3 \%$ of exporters producing $30.2 \%$ of export value and produce 13 times more patents per employee than large patenting firms (SBA, 2017). Supply chain management research has recognised the importance of maintaining small businesses in supply markets (Maloni \& Benton, 2000), highlighting that small businesses are disadvantaged relative to larger organisations in relational exchange and electronic communication, both important features of supplier relationships (Larson, Carr \& Dhariwal, 2005). Larger organisations struggle to align with small businesses in buyer-supplier relationships because of the difference between their sizes (Morya \& Dwivedi, 2009). In the public sector there is increasing concern about market dominance of larger firms over government contracts (Caldwell et al., 2005); to counteract this most governments wish to develop small businesses through improved engagement with public-sector contracts, but there is variability in their performance.

Private sector supply chain management research tells us that firms should develop their purchasing and supply chain management capability internally to leverage suppliers' resources to generate sustainable competitive advantage (Paulraj, 2011; Hitt, 2011; Barney, 2012). However, despite policies, legislation, regulation, and government-driven initiatives, 
governments are challenged to leverage supplier resources for the public good. In private sector supply chains, research evidence shows that integrated behaviour, cooperation and mutual sharing of information are important aspects of SCM to be effective in a competitive environment (Mentzer et al., 2001); building relational capital (Cousins et al., 2006) and trust (Zhang, Viswanathan \& Henke, 2011) are important for improved supply chain relationships But public-procurement regulations constrain public-sector buying organisations from developing closer, longer term relationships with suppliers.

Given that governments are large, powerful spending organisations that want to maintain and develop a thriving small business sector, this research examines the role of public procurement as a lever of government policy implementation. The manuscript makes multiple contributions. First, a review of literature finds the potential for public procurement as a strategic lever of supply chain reform to achieve broader government policy objectives to be underexploited. Second, small businesses as suppliers are examined both on their own and via engagement with public-procurement contracts, suggesting many reasons for developing small-business contributions to government supply chains, but challenges to secure those contributions.

Engaging small business in public procurement is critical, difficult, and understudied. This manuscript takes a first step to address this gap by using a framework based on policy feedback theory in a coproduction study. Data from 13 coproduced case studies representing 13 countries captured the perceptions of public-procurement practitioners and small-business associations of the effectiveness of different mechanisms used by government procurement to encourage and engage small businesses in supply chains. The mechanisms governments use to try to engage small businesses in supply chains supplying the public sector, and small business' interpretations of those, impact on their motivation to bid. Perceptions of effectiveness of mechanisms is explored; governments need to understand whether their chosen mechanisms 
impact small business capacity or predisposition to bid for contracts and engage in supply chains to the public sector. As small businesses represent such a substantial sector of economy and society in terms of employment, their satisfaction or dissatisfaction with government policy and its implementation should be important to governments. In private sector supply chains, it is understood how dedicated investments build trust and commitment in supply chain relationships (Nyaga, Whipple \& Lynch, 2010). Governments need to understand how they can do more to develop small businesses (Zeng, Xie \& Tam, 2010) by dedicating investments to engage them in public contracts (Preuss, 2011).

By applying policy feedback theory, this coproduced research provided insights to improve policy and public procurement in 13 countries, while addressing a gap in the literature on the empirical understanding of the types of mechanisms used by governments, and perceptions of governments and small businesses of the effectiveness of different mechanisms. It is found that type of mechanism used is important; governments are wasting investments in information and advice mechanisms, websites, and education, as small businesses perceive more value in direct and indirect financial support mechanisms that improve their resource capacity to engage with public contracts. It is also found that gaps in perceptions exist between policymakers, implementers, and targets of policy. The paper highlights the importance of public procurement and small businesses as under-studied areas of supply chain management. It also introduces policy feedback theory and coproduction research methods to the discipline and then shows how they can be used to engage in policy research.

\section{THEORETICAL BACKGROUND}

\section{Policy Feedback Theory}


Original research on policy feedback analysis (Pierson, 1993) highlighted that policymakers sought feedback from political elites rather than citizens. Pierson proposed that two main dynamics were at work in engaging citizens - resource effects (how the resources and incentives that policies provide shape patterns of behaviour) and interpretive effects (how policies convey meanings and information). Subsequent research developed these dynamics further through the provision of a policy feedback framework (Mettler, 2002), which examines engagement with public policy through using payments, goods and services, and applying rules and procedures to impact engagement. Originally applied to examine citizen engagement, this framework proposed that payments, along with goods and services provided to citizens, create resource effects that impact citizens' capacity and predisposition to engage with government policy. The framework also examines how rules and procedures give rise to interpretive effects that impact citizens' predisposition to engage. Our study applies this policy feedback framework (Figure 1) and develops it to examine small-business development policy performance, specifically through engaging small businesses in supply chains for goods and service provision to government i.e., using public procurement strategically to support small business policy implementation.

$<$ INSERT FIGURE 1 ABOUT HERE>

\section{The Strategic Role of Public Procurement}

The potential strategic role of public procurement is evident in its economic significance through the proportion that government spending represents of GDP internationally. OECD data shows that, in some economies, the impact of spending on GDP has a magnitude that cannot be neglected, like in France (57\%), Germany (44\%), Italy (50\%), Israel (40\%), the United Kingdom (42\%), and the United States (37\%), (OECD 2017). 
A portion of government spending is managed for procuring goods, services, and works for public services and state-owned enterprises; according to recent data, procurement cost impacts up to $20 \%$ of GDP, as in the Netherlands and Finland, (OECD, 2017). Research has provided evidence of how public procurement can impact broader government objectives; public procurement is central to stimulating innovation (Edler \& Georghiou, 2007; Uyarra \& Flanagan 2010; Lember, Kalvet \& Kattel, 2011), encouraging small-business entrepreneurship (Dennis Jr, 2011) and aiding industrial development (Dalpé, 1994). Public procurement is a mechanism for delivering social outcomes (McCrudden, 2004) and sustainability (Brammer \& Walker 2011, Fernández-Viñé, Gómez-Navarro \& Capuz-Rizo, 2013). Targeting where public service and construction contracts are placed impacts employment (Erridge, 2007). Italian research provides evidence of how public procurement improves quality of local public services and economic development (Vecchiato \& Roveda, 2014). Using public procurement to favour domestic suppliers impacts national economies (Trionfetti, 2000). Used strategically, public procurement can promote competition in supply markets (Caldwell et al., 2005).

Public procurement can be an important lever for government policy implementation to impact business, economy, and society (Harland, Telgen \& Callender, 2013). It can support and drive the delivery of broader government policy objectives (Knight et al., 2007), but additional empirical research is required to guide governments on how to do this.

\section{Engaging Small Businesses in Public-Procurement Contracts}

Small businesses are important to business, economy, and society in terms of employment and contribution to GDP (Meghana, Beck \& Demirguc-Kunt, 2007), developing labour markets through job creation (Lukács, 2005), and transition economies (Smallbone \& Welter, 2001). Literature examining issues of small-business engagement in publicprocurement contracts can be found in the public-procurement and small-business literatures 
(Schubert \& Legner, 2011). The intersection of these two literatures is in the body of research examining small-business engagement in public-procurement contracts. Within this is literature relating to research on mechanisms of how to engage small businesses in publicprocurement contracts. However, despite the recognition of the importance of small businesses, there is evidence that more could be done by governments to ensure their future well-being (Zeng, Xie \& Tam, 2010). Small businesses have expressed concerns about the limited support they receive (Loader, 2015).

Public procurement can play a key role in engaging small businesses in public-sector contracts (Aschhoff \& Sofka, 2009) and contribute to achievement of performance in terms of entrepreneurship and development of the small-business sector (Preuss, 2011), particularly in regions of economic distress (Aschhoff \& Sofka, 2009). However, whilst public procurement might try to engage small businesses in public sector contracts, this is not being successfully achieved consistently across different countries.

On one side of government small-business relationships, micro firms are particularly disadvantaged because of lack of resource slack, and are less likely to bid for and successfully win tenders for public contracts (Flynn, McKevitt \& Davis, 2015). Small businesses lack awareness of opportunities, ability to get on approved supplier lists, and knowledge of public sector procurement processes (Loader, 2011); they perceive inertia of public sector organisations in choosing suppliers, restrictive environmental requirements placed on bidders, and that bidders need a strong previous track record (Loader, 2011). Small businesses' perceptions of their own resources and capabilities has been shown to influence their willingness to attempt to engage in public-procurement contracts (Karjalainen \& Kemppainen, 2008), and excessive bureaucracy and paperwork penalises those with fewer resources and less slack (Albano et al., 2015). The trend towards government procurement contracting for complex 'one-stop shop' packages of services and products, rather than separate services and 
products into different contracts, also favours larger firms that can offer a more complex portfolio (Hartmann et al., 2014).

On the other side of government small-business relationships, public-procurement practitioners lack clear priorities and objectives, hampering improvement of engaging small businesses in public sector contracts. They are less likely to mentor and support small businesses than budget holders for whom the contract is being let (McKevitt \& Davis, 2015), and poor data on suppliers impedes targeted improvements (Loader, 2013). A survey conducted in Ireland found that, despite the existence of government policy to encourage increased engagement of small businesses in public contracts, there is limited evidence of successful implementation of this policy (Flynn \& Davis, 2015).

Recent survey research has shown that government sources of advice have limited impact and many small businesses make little use of external business advice (Stoian, Dimitratos \& Plakoyiannaki, 2018). Even where government targets for small-business engagement in public contracts are set, achieving these targets is problematic (Kidalov \& Snider, 2011), and there are straightforward reasons for this. First, despite private sector supply chain research showing the importance of longer term, more integrated relationships with suppliers (Mentzer et al., 2001; Cousins et al., 2006, Zhang, Viswanathan, \& Henke Jr, 2011), the strict legal and accountability frameworks within which public procurement has to operate can be constraining (Ya Ni \& Bretschneider, 2007) and can impede public-procurement practitioners' abilities to collaborate with suppliers on complex details of specifications associated with larger infrastructure projects (Lenferink, Tillema \& Arts, 2013). A more distant relationship with public-procurement practitioners and their tendency to over-specify contract requirements, rather than procure outcomes, also inhibits innovative suppliers' abilities to secure public contracts (Uyarra et al., 2014). The cyclical and geographically bounded nature 
of many local-authority purchases can restrict contracting more-radical, disruptive innovations and favour incremental, less-radical purchases (Dale-Clough, 2015).

\section{Mechanisms to Engage Small businesses in Public-Procurement Contracts}

In private sector supply chains there is research evidence of the difficulties of small businesses to manage their working capital (Caniato et al., 2016; Gelsomino et al., 2016). Small businesses have difficulty accessing credit to ease working capital constraints (Lekkakos \& Serrano, 2016). As a result, supply chain finance solutions have emerged to support working capital constrained supply chains (Wuttke et al., 2013; Caniato et al., 2016; Gelsomino et al., 2016). Contract mechanisms encouraging longer term supplier engagement in supply chains include risk and revenue sharing arrangements (Wakolbinger \& Cruz, 2011). However, these private sector developments have yet to transfer to supply chains serving the public sector.

Limited studies to date have focused on identifying mechanisms for publicprocurement organisations to engage small businesses successfully (Su-Yol \& Klassen, 2008; Eßig \& Glas, 2016; Glas \& Eßig, 2018). Table 1 lists these studies.

\section{<INSERT TABLE 1 ABOUT HERE>}

These studies are mainly focused on the initiatives to overcome engagement barriers, and do not include more recent creative mechanisms emerging in private sector supply chains. Individual studies have tended to focus on single mechanisms and there is little evidence of empirical research to explore which combinations of mechanisms are used by publicprocurement organisations.

Some research demonstrates that governments have attempted to improve engagement with small businesses by providing or subsidising advice (Turok \& Raco, 2000), and that this has been shown to have limited impact, possibly because the general business advice made 
available does not address specific needs of the heterogeneous small-business supply community (Curran \& Storey, 2002). Therefore, a gap exists in knowledge of which mechanisms may be more effective to engage small businesses in bidding for publicprocurement contracts. To fill this gap, two research questions are asked:

RQ1: Which mechanisms are being used by public-procurement organisations to engage small businesses in bidding for public contracts?

RQ2: Are patterns evident in the number and combination of mechanisms deployed by public-procurement organisations?

Furthermore, research to date has focused on the organisational unit of analysis, rather than the relationship. Some studies (e.g., (Su-Yol \& Klassen, 2008; Loader, 2011)) examine small businesses' views of government initiatives, rather than exploring both small-business and government views using a dyadic level unit of analysis. Organisational views of what is required and what happens in relationships may differ between both parties to the dyadic relationship; deeper understanding of gaps in perceptions of both parties is required to tease out reasons why governments continue to use mechanisms that are not favoured by small businesses. It has been shown that governments, in the main, recognise the significance of small businesses and have created policies to help develop the small business sector. It has also been shown that they recognise the potential strategic role of public-procurement contracting in implementing these policies. Some research evidence has shown that small businesses are dissatisfied with efforts and performance of engaging them in public-procurement contracts (Glas \& Essig, 2018). In line with this, and guided by the framework provided previously in Figure 1, a third research question is asked:

RQ3: What are public procurement and small business perceptions of performance of mechanisms to impact small business capacity and predisposition to engage in public contracts? 


\section{RESEARCH METHODS}

The research exploits a combination of qualitative and quantitative methods to collect and analyse data, an approach that is considered suitable when used for development purposes as proposed by the Tashakkori \& Teddlie (1998) model. In our case, we use case-based coproduction of research between academics and senior public-procurement practitioners for the preparation of case studies, their discussion, and validation.

Inductive theorising through qualitative research is very appropriate in understudied empirical situations (Bansal, Smith \& Vaara, 2018). Some scholars propose that if knowledge is to be relevant to management decision making, it should be coproduced by academics and practitioners (Starkey \& Madan, 2001; Van de Ven, 2007). Evidence-based management research (Pfeffer \& Sutton, 2006) enables collection of rich data through close connections with practitioners (Mohrman \& Lawler, 2011). Coproduction of research provides a distinct orientation to inquiry (Heron \& Reason, 2006) and a particular approach to case study research (McManners, 2016). It involves practitioners, not just in designing the research question and collecting the data, but also sense-making of the findings (Shani, 2017). The role of the practitioner in coproduction of research can range from providing requested data to leading, commissioning, and being involved in the design and exploitation of the research (Martin, 2010). Coproduction of research can improve research impact (Antonacopoulou, 2010; Armstrong \& Alsop, 2010).

The complex nature and scale of public procurement present challenges for empirical research (Patrucco et al., 2018), and it is understudied empirically (Caldwell et al., 2005). To address this scale and complexity, the study used a sequential, exploratory, mixed-methods design (Hanson et al., 2005), where senior public-procurement practitioners facilitated access to other public-procurement practitioners involved in small-business engagement, and also to 
associations representing small businesses. Practitioner members included the chief executive officer of the U.S. National Institute for Governmental Purchasing; a board director of the Chartered Institute of Purchasing and Supply; a deputy commander of the U.S. Naval Supply Systems Command; a regional director for the Office of Small and Medium Enterprises at Public Services and Procurement Canada; the executive director of the U.K. Office of Government Commerce; a deputy chief acquisition officer of the U.S. General Services Administration; the chief procurement officer, Norway; the director of the Dutch Public Procurement organisation, Pianoo; and the CEO of the Public Procurement and Disposal of Public Assets Authority, a member of Parliament and a High Court judge, all from Uganda.

Step 1, Sample of case studies: Initially, purposive sampling targeted senior publicprocurement practitioners and scholars worldwide. To take part in the study, each senior public-procurement practitioner and scholar pair were required to undertake research within their country over a six-month period, to develop a case study to a semi-structured template and commit to participate in a three-day workshop in Beijing to examine and develop the case studies. The resulting case studies therefore became a convenience sample, according to who was able and willing to devote the time and resources to satisfy these requirements; 13 case studies resulted, shown in Table 2.

\section{$<$ INSERT TABLE 2 ABOUT HERE>}

Step 2, case study template: The semi-structured template for the case studies is provided in Appendix 1, and this article relates to a subset of the data collected to populate the template. Scholar and practitioner teams were requested to seek out and interview appropriate senior executives in small-business associations and public-procurement organisations trying to engage small businesses. They were asked to trawl websites and documents, and complete 
semi-structured case study templates with qualitative and quantitative primary and secondary data provided by the public-procurement and small-business organisations they met and interviewed. Each case study coproduction team reported at the workshop how many face-toface interviews, further telephone interviews, emails to gather data, and efforts analysing websites of various government and small-business organisations they performed; typically, face-to-face and telephone interviews for each case numbered 9 to 15 . The academics and practitioners used snowballing to connect to appropriate personnel to answer as many questions in the template as possible. This exploited the local knowledge, contacts, and experience of those involved in collecting the data, in line with coproduced case study guidance (McManners 2016).

Step 3, coding and initial within and cross-case analysis: Coding was done through an iterative, multistep process, used elsewhere in case study research in the field of supply chain management (Pagell \& Wu, 2009). A case study summary table was created by a data analyst, extracting data from the populated case study templates. For the purposes of this research, starting from literature reported in Table 1, a separate table was created containing data relating to mechanisms used by public procurement to implement their governments' small-business policy. This coding was performed independently by the analyst and one of the research organisers across all 13 cases, and then jointly discussed and reconciled. In light of this, some labels derived from the literature were expanded - e.g., "provision of financial assistance to small businesses" was expanded to "provision of financial assistance: registration fees removed/deposits refunded/assistance loans" - and some mechanisms not previously reported in the literature were added to the coding structure. Case study coproducers were contacted to address omissions and queries with the populated templates prior to the workshop.

Step 4, workshop: The purpose of the workshop was to discuss and validate the data provided, explore and enrich the cases through questioning and comparison across the cases, and add to 
the data tables for each case study. Coproducer teams were asked to prepare presentations about their cases. Workshop participants included case study coproducers, senior representatives of the public-procurement profession (including chief executive and senior officers of professional procurement institutes), and the organising team of academics and student facilitators. The three-day workshop was designed to have parallel streams of case study presentations and in-depth questioning of several hours for each case, followed by plenary presentations across the streams. Participants probed each case, performing collaborative sense-making of the data (Shani, 2017). Plenary discussions were facilitated to draw out themes to question more deeply within subsequent parallel streams.

Step 5, post workshop within and cross-case analysis: Post workshop, each case study was analysed by the participating research organisers, data analyst and student facilitators; additional data was gleaned from the workshop and added to the case study tables. The resulting data tables were substantial; one of the challenges of coproduced research is the variety of data in terms of content and volume across the cases. The data tables appeared "ragged" in parts, in that some cases had very deep and rich data, and others less so. Identification of a core of reliable, relevant, and interesting data occurred through iterations of discussions across the organisers and the data analyst, frequently returning to the raw data and the coproducers for verification. The research organisers guided the data analyst on statistical tests to perform and questions to ask of the data, but also encouraged freedom to search for interesting findings of the data.

\section{FINDINGS}

\section{RQ1: Engagement Mechanisms Used by Governments}


Using policy feedback theory, mechanisms were classified as those that have tangible, practical impact on small business resource capacity building (C) and those that are more informational (I), impacting the predisposition of small businesses to engage in public contracts.

A wide variety of mechanisms is being used (some providing financial and capacitybuilding support, and others providing information and advice), with the establishment of a specialist unit for small businesses being the most commonly adopted (in 9 of 13 cases), followed by the provision of financial assistance (6 of 13). Table 3 shows the mechanisms used in each case and their classification (capacity building is $\mathrm{C}$; informational is I).

\section{<INSERT TABLE 3 ABOUT HERE>}

While most of the cases used between two and six mechanisms, China and Belgium emerge as outliers, the former for the largest amount of mechanisms being used (11) and the latter for the absence of usage of any mechanisms.

The China case provided evidence of the most comprehensive use of government policy to engage small businesses in public-procurement contracts and the most detailed use of strategy and its implementation to enact those policies. Public-procurement practitioners reported good performance by the extensive range of mechanisms they were using. The smallbusiness representative bodies interviewed supported the wide range of mechanisms being used to engage them and agreed they were performing well. They only raised one concern regarding variability in local implementation across different government departments and its lack of coordination at national level. This apparent dyadic harmony should be viewed with caution, however, as in China the small-business representative bodies are not independent, but a part of government. 
For the Belgian case, public-procurement practitioners reported that public procurement in Belgium is performed by lawyers - they had to comply with EU law; favouring small businesses works against the free market and is illegal. The coproducers of the case study stated:

\section{"The Single Market Act is not about small business promotion."}

This explains why public procurement did not use any mechanisms at all to favour or support small-business engagement. The small-business representative bodies interviewed believed some support should be possible within the law, and perceived government and public procurement as doing nothing. They perceived that public procurement's reliance on legislation disadvantaged them.

\section{RQ2: Patterns in Mechanisms Usage}

Two main patterns are evident from using cluster analysis. The first relates to the number of mechanisms used and is shown in Table 4; the analysis revealed the existence of four clusters. Two outlying cases based in China and Belgium formed their own clusters, while the other cases grouped into two clusters, one where 1-3 mechanisms (cases $\mathrm{J}, \mathrm{K}$ and L) were used and the other where 4-6 mechanisms were used (cases A, C, D, E, F, G, H, M).

\section{$<$ INSERT TABLE 4 ABOUT HERE>}

The second pattern emerged through analysing the nature of the mechanisms characterising the clusters. It is evident that where public procurement used only a few mechanisms (in cluster 1), these were capacity-building mechanisms. Where more mechanisms were used (in clusters 2 and 4), some informational mechanisms were used in addition to capacity building. 


\section{RQ3: Perceptions of Mechanism Effectiveness}

To address $R Q 3$, scores of perceptions of effectiveness were calculated and reported in Figure 2.

\section{$<$ INSERT FIGURE 2 ABOUT HERE>}

The top eight mechanisms favoured by small businesses all impact their resource capacity to engage with public contracts. The first five are forms of direct and indirect financial assistance. The biggest difference in small-business and public-procurement views is in performance of set-asides, favoured by small businesses but less so by public procurement. The reason two small-business scores are 0 is that these mechanisms were very new and not visible to small-business associations in this case, who ranked them as 0 , but the public-procurement practitioners who used them ranked them as highly effective.

Mechanisms favoured by public procurement more than small businesses were informational, attempting to impact predisposition to bid for public contracts. These findings were validated in the workshop, where public-procurement practitioners using informational mechanisms reinforced their views of them as highly effective. This sense-making of the data (Shani, 2017) provoked discussion and realisation of the public-procurement practitioners that perhaps they did not understand what small businesses need to bid for public contracts.

Finally, the highest-performing mechanism in terms of the combined scores was "Target economic development in small business-dominated areas, creating demand for smallbusiness products and services" - perceived as delivering equally well to the policy agenda and the small business target group.

\section{DISCUSSION}

\section{Types of Mechanisms Used to Engage Small Businesses}

While previous research has identified particular mechanisms to engage small businesses in bidding for public contracts, this is the first international empirical study that 
provides evidence of a wide range of mechanisms and their usage. In the workshop, a lack of knowledge across public-procurement practitioners about possible mechanisms other than the ones they were using was evident; they questioned each other with curiosity about other mechanisms and their implementation, and they were particularly interested in others' opinions of which mechanisms might be effective to engage small businesses. The theory-based coproduction methodology allowed practitioners to experience a learning process, which indicated that using public-procurement mechanisms to engage small businesses in public contracts as a means of implementing small-business development policy is a new area within which they have little experience. Practitioners seem to be experimenting, thinking up different ways to encourage small businesses to bid, but without knowing whether their investment in these initiatives will pay back with performance. The practitioners were fascinated with the China case, in which there was so much evidence of detailed research by the Chinese government on the small-business population across China and what mechanisms might encourage them to bid for government contracts. The research provides a foundation to change policy making and implementation in public procurement; it opens the door for more research on how government policies might be designed with implementation routes through public procurement in mind. It also raises questions for future research about how policy makers and public procurement practitioners might work together more effectively to use public procurement as a lever to support policy implementation.

\section{Perceptions of Mechanism Effectiveness}

The cases confirm that increasing engagement of small businesses in publicprocurement contracts could be a lever to implement broader policies supporting smallbusiness development; this supports prior research findings (Aschhoff \& Sofka, 2009). The findings also support the increasing recognition of governments that public procurement can 
be a lever to implement various policies (Knight et al., 2007; Lynch, Walker \& Harland, 2013). However, to date, there has not been empirically supported understanding of perceptions of effectiveness of particular mechanisms.

The categorisation of mechanisms into those that impact supply chain resource capacity and those that are more informational is novel and has not previously appeared in supply chain management literature. Those impacting resource capacity were direct provision of finance or resources, or improving cash flow, all of which were important to small businesses, as shown in the example quotation.

“...underlying issue of long payment times to suppliers is not being addressed”, Uganda, small business body

Mechanisms to reduce supply chain costs through reducing bureaucracy, rigidity and simplifying processes in contracting include the use of incomplete contracts (Williamson, 2008); notable use of incomplete contracts is evident in contracting for Heathrow Terminal 5 (Caldwell, Roehrich \& Davis, 2009). These have been used in large complex publicprocurement Public Private Partnership (PPP) and Private Finance Initiatives (PSI) contracts (Zheng, Roehrich \& Lewis, 2008), but such mechanisms are not commonly used in traditional, routine public procurement contracting where bureaucracy and unwieldy processes are evident, as highlighted in the quote below:.

“Too many copies, not enough time (or trees)” Canada, small business body

The findings on choices and combinations of mechanisms revealed variety across the cases that was explored more deeply in the workshop. In some cases, such as all those in cluster 1 and some in cluster 4, such as Uganda and South Africa, there was a clear, deliberate focus on use of capacity-building mechanisms. Particularly in Uganda and South Africa, public procurement worked closely with ministers forming policy and also with the small business community; they knew what was required and how to implement small business policy 
effectively through public procurement. In others, a greater detachment and disconnection of policymakers, public procurement and the small business community was evident. In these cases, public-procurement bodies were trying to engage small businesses but only guessing which mechanisms might work.

"The actual magnitude of the problem is not known; the government assumes that (too) few small businesses are bidding and/or winning public orders, but there is no clear quantitative overview of the problem." Norway, public procurement

There emerged a sense of clear targeting in some cases but a scattergun approach in others; in the latter set there was more use of informational mechanisms and lack of awareness that small businesses did not favour these. This research shows that small businesses favour mechanisms that improve their resource capacity to bid for public contracts. Lack of resource slack in small businesses disadvantages them in bidding for and successfully winning tenders for public contracts (Flynn, McKevitt \& Davis, 2015). This might encourage the use of mechanisms that break down size of tenders, such as the use of smaller contracts and 'bundling' (Hartmann et al., 2014) or that reduce the bureaucracy and costs of bidding for public contracts (Loader, 2011).

Policies, laws, and regulations vary internationally and restrict or promote the use of particular mechanisms to engage small businesses in public-procurement contracts. It is also evident that interpretation of these policies, laws, and regulations varies internationally and within countries between central and local government. Differences in use of mechanisms also reflect local initiatives, creativity, and determination to engage small businesses in public procurement. During the workshop, it became clear that the public procurement practitioners involved had not had insight into the use of mechanisms and their effectiveness, other than those used in their own domains. 
The top five mechanisms favoured by small businesses are all financially oriented, and many they perceive as less effective are to do with websites, information, measuring, and monitoring - i.e., more information oriented mechanisms. But financially oriented mechanisms are more open to corruption and abuse, as highlighted in the quote below:

"Everything is there in place, but there is dishonesty."-South Africa, public procurement

So while these mechanisms are favoured by small businesses and are potentially more effective, there is a cost burden and a responsibility upon public procurement to police their ethical deployment.

\section{Reflecting on Policy Feedback Theory}

In addressing RQ1, the findings provide evidence that the governments involved in this research expect to support small businesses in their engagement with public-procurement contracts through policies and the use of various mechanisms. Only in one case study - case I, based in Belgium - was this not the case. This shows that these governments recognise the significance of small-business development, as found in prior literature (Smallbone \& Welter, 2001; Lukács,2005; Meghana, Beck \& Demirguc-Kunt, 2007).

In this study, the public policy in focus is supporting the development of smaller businesses, and its implementation is through encouraging engagement of smaller businesses in public contracts. The "payments, goods, and services" are the direct financial support provided by governments to increase the resource capacity of small businesses to bid for public contracts using mechanisms such as set-asides, targeted economic development, prompt payments, and provision of financial assistance. These mechanisms result in resource effects that improve the capacity of smaller businesses to bid for public contracts and improve their predisposition towards bidding for public contracts. 
The "rules and procedures" that give rise to interpretive effects and impact the predisposition of small businesses to engage with the policy are the more informational mechanisms, such as monitoring and measuring, websites, publicity, and online help: We have further developed the policy feedback framework in Figure 3, applying it to the use of public procurement to implement small-business development policy.

\section{$<$ INSERT FIGURE 3 ABOUT HERE $>$}

Policy feedback research has provided evidence that participation of key individuals in policy forming increases policy performance (Mettler, 2002). Policymakers and public policy research have been criticised for focusing most attention on policy forming rather than policy implementing, and for assessing macro-level influences of policy on industries rather than having dialogues with individual organisations (Hiatt \& Park, 2013). In some of the case studies where a wide range of mechanisms are used, many of which are not perceived as valuable by smaller businesses, there is more of an impression of "arms-length" rather than "evidence-based" policy making. Small-business researchers have identified that smallbusiness leaders are not sufficiently engaged in policy feedback and are consistently omitted from policy debates (Baden, Harwood \& Woodward, 2011).

There is also evidence from the cases of issues with implementation. Even when the policy is in place and mechanisms are available to public procurement to implement it, there are barriers to implementation, as highlighted in the quotes below:

“Goals aren't being achieved because the government treats policy as aspirational and looks for loopholes to avoid small-business awards. " - U.S. public procurement "Government finds best practices, copies them into policy, but then doesn't adopt them." Hungary public procurement 
“... as you move further from central government, unsurprisingly there's a focus on keeping work in the local economy; some may refer to this negatively as "protectionism." - U.K. public procurement

So, while the developed framework implies that using direct, financially oriented mechanisms will lead to small-business engagement in public contracts, there are plenty of obstacles to successful implementation. The framework was theoretically informed and then enhanced via the coproduction methodology. In the process of creating the framework the participants were exposed both to other options and the thinking of other members of the supply chain; this should change future outcomes.

\section{CONCLUSIONS}

The list of mechanisms used by governments to engage small businesses in public procurement is novel in both its content and the empirical methodology of how it was derived; it provides a useful contemporary checklist for governments to reflect on the mechanisms they are using. Available policy levers to engage small businesses have been categorised into two groups (Dennis Jr., 2011): those that remove existing barriers to entry for small businesses, and those that motivate and provide support for them. This research goes further by identifying the two types and popularity of different mechanisms and gaps in perceptions relating to each mechanism between public procurement and the small-business community. Future research needs to extend these methods to other problems and explore if these mechanisms would have further applications either in public procurement or other policy areas.

Small-business access to external resources has been found to be critical in engaging them in environmental improvements (Lee \& Klassen, 2008). It is logical that, as small 
businesses are resource constrained, engaging them in any additional initiative would be more likely to succeed if financial inducements are made; this has been highlighted in private sector supply chains (Nyaga, Whipple \& Lynch, 2010). This research has provided details of the most successful mechanisms perceived by small businesses, all of which give them financial support or reduce cost burdens. These mechanisms would seemingly apply to private procurement as well; future research should test that supposition.

Supply chain management research provides evidence of the benefits of close, more integrated supply chain relationships (Mentzer et al., 2001; Cousins et al., 2006, Zhang, Viswanathan \& Henke Jr., 2011). Public-procurement practitioners in countries where mechanisms were more informational appeared more at arms' length and remote from the voice of small businesses, exhibiting signs of a "we know best" attitude or "we don't know, so we're guessing". Problems relating to these gaps in communication have been highlighted previously (Ramsden \& Bennet, 2005; Kidalov \& Snider, 2011; Loader, 2011; Kidalov, 2013; Loader, 2015). When asked, small businesses were consistent in their responses that they need resource support, not information or general business advice (Bennett \& Robson, 1999; Curran \& Storey, 2002). Given that most supplier development efforts in the private sector are informational, this finding suggests that there is a need for more research on supplier development, with a particular focus on developing small suppliers.

Reflecting on policy feedback theory, this research has extended the application potential of the policy feedback framework to consider beyond the policymakers/ citizens relationship. This framework has been applied here in the government-to-business $(\mathrm{G} 2 \mathrm{~B})$ relationship whereas, originally, it was used only to examine the government-to-citizen (G2C) relationship. This may prompt other researchers to apply it to examine policy formation and implementation relating to other $\mathrm{G} 2 \mathrm{~B}$ contexts, such as customs and excise, environmental sustainability, and employment. The theory seems especially amenable to engaged methods 
such as coproduction; future supply chain research looking to drive change both in the policy realm and outside of it may be well served by exploring such engaged scholarship methods.

The research also shows the power of the methods. Public-procurement practitioners tend to stay in their locale and funds are usually limited for them to participate in international learning. This research enables public practitioners to learn about practices in other jurisdictions. The findings reveal surprises for two groups of government-procurement practitioners: first, those who are enthusiastic about their initiatives to engage small businesses and perceive them as performing well, but who learn that small businesses have different views; and, second, those who think their initiatives are good but are frustrated that improved smallbusiness engagement is not evident. In both groups, public-procurement practitioners' lack of understanding of small businesses' perceptions of the value of particular mechanisms is illuminating to them. Other supply chain practitioners would have similar limitations on their desire to learn; future research using coproduction and other theoretically informed engaged methods could help to span these gaps.

There is potential to position this and subsequent research more clearly in the supply chain management corporate social responsibility (CSR) field, where there has been research on small business engagement in CSR supply chain initiatives (Ciliberti, Pontrandolfo, \& Scozzi, 2008; Rahbek, 2009). Supporting small businesses can impact economy, society, and environment. Greater exploration of the role of public procurement in supporting delivery of CSR policies would usefully connect the fields of public procurement, supply chain management, and CSR more explicitly.

Finally, operations and supply chain management journals need to broaden their horizons to publish more research on public sector service supply chains. In particular the power of public procurement to impact on supply chains is an important area for future supply chain management research. The significant role that public procurement can play in 
supporting implementation of broader government policies is an important topic for future research, with the potential for supply chain management research to integrate with policy research. Research in private sector supply chains may benefit from learning about policy implementation from public administration research. Public procurement research in particular, should not be confined to specialist public administration and public procurement journals as the potential for future research to influence supply chains and organisations with them is profound. 


\section{References}

Albano, G. L., Antellini Russo, F., Castaldi, G., \& Zampino, R. (2015). Evaluating Small Businesses' Performance in Public e-Procurement: Evidence from the Italian Government's e-Marketplace. Journal of Small Business Management, 53, 229-250.

Amann, M., K. Roehrich, J., Eßig, M., \& Harland, C. (2014). Driving sustainable supply chain management in the public sector: The importance of public procurement in the European Union. Supply Chain Management: An International Journal, 19(3), 351366.

Antonacopoulou, E. P. (2010). Beyond co-production: practice-relevant scholarship as a foundation for delivering impact through powerful ideas. Public Money \& Management 30(4): 219-226.

Armstrong, F. and A. Alsop (2010). Debate: Co-production can contribute to research impact in the social sciences. Public Money \& Management 30(4): 208-210.

Aschhoff, B. and W. Sofka (2009). Innovation on demand-Can public procurement drive market success of innovations? Research policy 38(8): 1235-1247.

Baden, D., Harwood, I. A., \& Woodward, D. G. (2011). The effects of procurement policies on 'downstream'corporate social responsibility activity: Content-analytic insights into the views and actions of SME owner-managers. International Small Business Journal, 29(3), 259-277.

Bansal, P., Smith, W. K., \& Vaara, E. (2018). New ways of seeing through qualitative research. Academy of Management Journal 61, 4, 1189-1195

Barney, JB (2012). Purchasing, supply chain management and sustained competitive advantage: The relevance of resource-based theory. Journal of supply chain management , 48 (2), 3-6.

Bennett, R. J. and P. J. A. Robson (1999). The use of external business advice by SMEs in Britain. Entrepreneurship and Regional Development 11(2): 155-180.

Booth, L. (2011). Public procurement: small businesses and savings. Economy Policy and Statements-Programme for Government, May.

Brammer, S. and H. Walker (2011). Sustainable procurement in the public sector: an international comparative study. International Journal of Operations \& Production Management 31(4): 452-476.

Broecker, E. and F. Beraldi (2017). Offsets in public-sector procurement: tools for economic development or avenues for corruption? OECD Global Anti-Corruption and Integrity Forum.

Bruce, M., Daly, L., \& Towers, N. (2004). Lean or agile: a solution for supply chain management in the textiles and clothing industry?. International journal of operations \& production management, 24(2), 151-170. 
Caldwell, N., Walker, H., Harland, C., Knight, L., Zheng, J., \& Wakeley, T. (2005). Promoting competitive markets: the role of public procurement. Journal of Purchasing and supply management, 11(5-6), 242-251..

Caldwell, N. D., Roehrich, J. K., \& Davies, A. C. (2009). Procuring complex performance in construction: London Heathrow Terminal 5 and a Private Finance Initiative hospital. Journal of Purchasing and Supply Management, 15(3), 178-186.

Caniato, F., Gelsomino, L. M., Perego, A., \& Ronchi, S. (2016). Does finance solve the supply chain financing problem?. Supply Chain Management: An International Journal, 21(5), 534-549.

Ciliberti, F., Pontrandolfo, P., \& Scozzi, B. (2008). Investigating corporate social responsibility in supply chains: a SME perspective. Journal of cleaner production, 16(15), 1579-1588.

Cousins, P. D., Handfield, R. B., Lawson, B., \& Petersen, K. J. (2006). Creating supply chain relational capital: the impact of formal and informal socialization processes. Journal of operations management, 24(6), 851-863.

Cousins, P. D., Lawson, B., \& Squire, B. (2006). An empirical taxonomy of purchasing functions. International Journal of Operations \& Production Management, 26(7), 775-794.

Curran, J. and D. J. Storey (2002). Small business policy in the United Kingdom: the inheritance of the Small business Service and implications for its future effectiveness. Environment and Planning C: Government and Policy 20(2): 163-177.

Dale-Clough, L. (2015). Public procurement of innovation and local authority procurement: procurement modes and framework conditions in three European cities, Innovation: The European Journal of Social Science Research, 28(3), 220-242

Dalpé, R. (1994). Effects of government procurement on industrial innovation. Technology in Society 16(1): 65-83.

Denes, T. A. (1997). Do small business set-asides increase the cost of government contracting? Public Administration Review: 441-444.

Dennis Jr, W. J. (2011). Entrepreneurship, small business and public policy levers. Journal of Small business Management 49(1), 92-106.

Edler, J. and L. Georghiou (2007). Public procurement and innovation-Resurrecting the demand side. Research Policy 36(7), 949-963.

Eisenhardt, K. M. (1989). Building theories from case study research. Academy of management review 14(4), 532-550.

Eisenhardt, K. M., Graebner, M. E., \& Sonenshein, S. (2016). Grand challenges and inductive methods: Rigor without rigor mortis. Academy of Management Journal, 59(4), 11131123 
Ellram, L. M., Tate, W. L., \& Billington, C. (2004). Understanding and managing the services supply chain. Journal of Supply Chain Management, 40(3), 17-32.

Erridge, A. (2007). Public procurement, public value and the Northern Ireland unemployment pilot projec. Public Administration, 85(4): 1023-1043.

Eßig, M. and A. H. Glas (2016). Considering Small and Medium-Sized Suppliers in Public Procurement - The Case of the German Defence Sector. Logistics Management, Springer: $19-33$.

Fernandes, T. and V. Vieira (2015). Public e-procurement impacts in small-and mediumenterprises. International Journal of Procurement Management 8(5): 587-607.

Fernández-Viñé, M. B., Gómez-Navarro, T., \& Capuz-Rizo, S. F. (2013). Assessment of the public administration tools for the improvement of the eco-efficiency of Small and Medium Sized Enterprises. Journal of Cleaner Production, 47, 265-273..

Flynn, A. and P. Davis (2015). The rhetoric and reality of SME-friendly procurement. Public Money and Management 35(2): 111-118.

Flynn, A., McKevitt, D., \& Davis, P. (2015). The impact of size on small and medium-sized enterprise public sector tendering. International Small Business Journal, 33(4), 443461.

Gelsomino, L. M., Mangiaracina, R., Perego, A., \& Tumino, A. (2016). Supply chain finance: a literature review. International Journal of Physical Distribution \& Logistics Management, 46(4), 348-366.

Georghiou, L., Edler, J., Uyarra, E., \& Yeow, J. (2014). Policy instruments for public procurement of innovation: Choice, design and assessment. Technological Forecasting and Social Change, 86, 1-12.

Gibbons, M. (1994). The new production of knowledge: The dynamics of science and research in contemporary societies, Sage.

Glas, A. H. \& M. Eßig (2018). Factors that influence the success of small and medium-sized suppliers in public procurement: evidence from a centralized agency in Germany. Supply Chain Management: An International Journal, 23(1): 65-78.

Hafezalkotob, A. (2015). Competition of two green and regular supply chains under environmental protection and revenue seeking policies of government. Computers \& Industrial Engineering, 82, 103-114.

Hall, J., \& Matos, S. (2010). Incorporating impoverished communities in sustainable supply chains. International Journal of Physical Distribution \& Logistics Management, 40(1/2), 124-147

Hallikas, J., Puumalainen, K., Vesterinen, T., \& Virolainen, V. M. (2005). Risk-based classification of supplier relationships. Journal of Purchasing and Supply Management, 11(2-3), 72-82.. 
Hamet, J. and S. Michel (2018). Rigor, relevance, and the knowledge "market". European Business Review 30(2): 183-201.

Hanson, W. E., Creswell, J. W., Clark, V. L. P., Petska, K. S., \& Creswell, J. D. (2005). Mixed methods research designs in counseling psychology. Journal of counseling psychology, 52(2), 224.

Harland, C., Telgen, J., \& Callender, G. (2013). International research study of public procurement. The SAGE handbook of strategic supply management, 374-401.

Hartmann, A., Roehrich, J., Frederiksen, L., \& Davies, A. (2014). Procuring complex performance: the transition process in public infrastructure. International journal of operations \& production management, 34(2), 174-194.

Heron, J. \& P. Reason (2006). The practice of co-operative inquiry: Research 'with'rather than 'on'people. Handbook of action research 2: 144-154.

Hiatt, S. R. \& S. Park (2013). Lords of the harvest: Third-party influence and regulatory approval of genetically modified organisms. Academy of management journal 56(4): 923-944.

Hitt, MA (2011). Relevance of strategic management theory and research for supply chain management. Journal of Supply Chain Management , 47 (1), 9-13.

Johnson, P. F., Shafiq, A., Awaysheh, A., \& Leenders, M. (2014). Supply organizations in North America: A 24 year perspective on roles and responsibilities 19872011. Journal of Purchasing and Supply Management, 20(2), 130-141.

Karjalainen, K. \& K. Kemppainen (2008). The involvement of small- and medium-sized enterprises in public procurement: Impact of resource perceptions, electronic systems and enterprise size. Journal of Purchasing and Supply Management 14(4): 230-240.

Kidalov, M. V. (2013). U.S. and E.U. SME subcontracting policy and practice trends: Towards a transatlantic accountability consensus. Journal of Public Procurement 13(1): 39-71.

Kidalov, M. V. \& K. F. Snider (2011). US and European public procurement policies for small and medium-sized enterprises (SME): A comparative perspective. Business and Politics 13(4).

Kidalov, M. V. \& K. F. Snider (2011). US and European public procurement policies for small and medium-sized enterprises (SME): a comparative perspective. Business and Politics 13(4): 1-41.

Klassen, R. D., \& Vachon, S. (2003). Collaboration and evaluation in the supply chain: The impact on plant-level environmental investment. Production and Operations Management, 12(3), 336-352

Knight, L., Harland C, Telgen J., Thai K, Callender G. \& McKen K (2007). Public procurement: International cases and commentary, Routledge. 
Larson, Paul D., Peter Carr, \& Kewal S. Dhariwal. SCM involving small versus large suppliers: relational exchange and electronic communication media. Journal of supply chain management 41.1 (2005): 18-29.

Lee, S. Y. \& R. D. Klassen (2008). Drivers and enablers that foster environmental management capabilities in small-and medium-sized suppliers in supply chains. Production and Operations Management 17(6): 573-586.

Lekkakos, S. D., \& Serrano, A. (2016). Supply chain finance for small and medium sized enterprises: the case of reverse factoring. International Journal of Physical Distribution \& Logistics Management, 46(4), 367-392.

Lember, V., Kalvet, T., \& Kattel, R. (2011). Urban competitiveness and public procurement for innovation. Urban Studies, 48(7), 1373-1395..

Lenferink, S., Tillema, T., \& Arts, J. (2013). Public-private interaction in contracting: Governance strategies in the competitive dialogue of dutch infrastructure projects. Public Administration, 91(4), 928-946.

Loader, K. (2011). Are public sector procurement models and practices hindering small and medium suppliers? Public Money and Management 31(4): 287-294.

Loader, K. (2011). Are public sector procurement models and practices hindering small and medium suppliers? Public Money \& Management 31(4): 287-294.

Loader, K. (2013). Is public procurement a successful small business support policy? A review of the evidence. Environment and Planning C: Government and Policy 31(1): $39-55$.

Loader, K. (2015). SME suppliers and the challenge of public procurement: Evidence revealed by a UK government online feedback facility. Journal of Purchasing and Supply Management 21(2): 103-112.

Lukács, E. (2005). The economic role of SMEs in world economy, especially in Europe. European Integration Studies 1 (4): 3-12.

Lynch, J., Walker, H, \& Harland, C (2013). Utilizing a community benefits tool in support of the local multiplier effect for sustainable procurement innovation, United Nations. Supplement to the 2013 Annual Statistical Report.

MacManus, S. A. (1991). Why Businesses are Reluctant to Sell to Governments. Public Administration Review 51(4): 328-344.

Maloni, M., \& Benton, W. C. (2000). Power influences in the supply chain. Journal of business logistics, 21(1), 49-74.

Maréchal, F. \& P.-H. Morand (2012). Small business participation procurement policy: Subcontracting vs allotment. Recherches économiques de Louvain 78(2): 5-23.

Marion, J. (2007). Are bid preferences benign? The effect of small business subsidies in highway procurement auctions. Journal of Public Economics 91(7-8): 1591-1624. 
Martin, S. (2010). Co-production of social research: strategies for engaged scholarship. Public Money \& Management 30(4): 211-218.

McCrudden, C. (2004). Using public procurement to achieve social outcomes. Natural Resources Forum 28(4): 257-267.

McKevitt, D. \& P. Davis (2015). How to interact, when and with whom? SMEs and public procurement. Public Money and Management 35(1): 79-86.

McManners, P. (2016). The action research case study approach: A methodology for complex challenges such as sustainability in aviation. Action Research 14(2): 201-216.

Meghana, A., Beck, T., \& Demirgüç-Kunt, A. (2007). Small and medium enterprises across the globe. Small Business Economics, 29(4), 415-434.

Mettler, S. (2002). Bringing the state back in to civic engagement: Policy feedback effects of the GI Bill for World War II veterans. American Political Science Review 96(2): 351365 .

Mentzer, J. T., DeWitt, W., Keebler, J. S., Min, S., Nix, N. W., Smith, C. D., \& Zacharia, Z. G. (2001). Defining supply chain management. Journal of Business logistics, 22(2), 125.

Mohrman, S. A. \& E. Lawler (2011). Research for theory and practice. Useful research: Advancing theory and practice: 9-33.

Morya, K. K., \& Harsh Dwivedi. Aligning interests of SMEs and a focal firm (MNE) in a global supply chain setup. Journal of Supply Chain Management 6.1 (2009): 49-59.

Nakabayashi, J. (2013). Small business set-asides in procurement auctions: An empirical analysis. Journal of Public Economics 100: 28-44.

Nyaga, G. N., Whipple, J. M., \& Lynch, D. F. (2010). Examining supply chain relationships: do buyer and supplier perspectives on collaborative relationships differ?. Journal of operations management, 28(2), 101-114

OECD (2017), Government at a Glance 2017, OECD Publishing, Paris, https://doi.org/10.1787/gov_glance-2017-en.

Pagell, M. \& Z. Wu (2009). Building a more complete theory of sustainable supply chain management using case studies of 10 exemplars. Journal of Supply Chain Management 45(2): 37-56.

Patrucco, A. S., Walker, H., Luzzini, D., \& Ronchi, S. (2018). Which shape fits best? Designing the organizational form of local government procurement. Journal of Purchasing and Supply Management. (In press) https://doi.org/10.1016/j.pursup.2018.06.003

Paulraj, A. (2011). Understanding the relationships between internal resources and capabilities, sustainable supply management and organizational sustainability. Journal of Supply Chain Management , 47 (1), 19-37. 
Pfeffer, J. \& R. I. Sutton (2006). Evidence-based management. Harvard Business Review 84(1): 62.

Pierson, P. (1993). When effect becomes cause: Policy feedback and political change. World Politics 45(4): 595-628.

Preuss, L. (2011). On the contribution of public procurement to entrepreneurship and small business policy. Entrepreneurship \& Regional Development 23(9-10): 787-814.

Punj, G. and D. W. Stewart (1983). Cluster analysis in marketing research: Review and suggestions for application. Journal of Marketing Research: 134-148.

Rahbek Pedersen, E. (2009). The many and the few: rounding up the SMEs that manage CSR in the supply chain. Supply Chain Management: An International Journal, 14(2), 109116.

Ram, M., Theodorakopoulos, N., \& Worthington, I. (2007). Policy transfer in practice: implementing supplier diversity in the UK. Public Administration, 85(3), 779-803.

Ramsden, M., \& Bennett, R. J. (2005). The benefits of external support to SMEs: "Hard" versus "soft" outcomes and satisfaction levels. Journal of Small Business and Enterprise Development, 12(2), 227-243.

Rao, P. (2002). Greening the supply chain: a new initiative in South East Asia. International Journal of Operations \& Production Management, 22(6), 632-655

Rasheed, H. S. (2004). Capital access barriers to public procurement performance: the moderating effects of ethnicity, gender and education. Journal of Developmental Entrepreneurship 9(2): 22-43.

Sahay, B.S., \& Mohan, R. (2003). Supply chain management practices in Indian industry. International Journal of Physical Distribution \& Logistics Management, 33(7), 582606

Sarkis, J. (2012). A boundaries and flows perspective of green supply chain management. Supply chain management: an international journal, 17(2), 202-216.

SBA (2017) https://www.sba.gov/advocacy/small-business-economy, accessed 27.04.2017

Schubert, P. \& C. Legner (2011). B2B integration in global supply chains: An identification of technical integration scenarios. The Journal of Strategic Information Systems 20(3): 250-267.

Shani, A. B. R. (2017). Knowledge and practice: a historical perspective on collaborative management research. Academic-Practitioner Relationships, Routledge: 39-56.

Smallbone, D. \& F. Welter (2001). The role of government in SME development in transition economies. International Small business Journal 19(4): 63-77.

Starkey, K. \& P. Madan (2001). Bridging the relevance gap: Aligning stakeholders in the future of management research. British Journal of Management 12: S3-S26. 
Stoian, M. C., Dimitratos, P., \& Plakoyiannaki, E. (2018). SME internationalization beyond exporting: A knowledge-based perspective across managers and advisers. Journal of World Business, 53(5), 768-779.

Su-Yol, L. \& R. D. Klassen (2008). Drivers and Enablers That Foster Environmental Management Capabilities in Small- and Medium-Sized Suppliers in Supply Chains. Production \& Operations Management 17(6): 573-586.

Tashakkori, A., \& Teddlie, C. (1998). Mixed methodology: Combining qualitative and quantitative approaches (Vol. 46). Sage.

Trionfetti, F. (2000). "Discriminatory public procurement and international trade. The World Economy 23(): 57-76.

Turok, I. \& M. Raco (2000). Developing expertise in small and medium-sized enterprises: an evaluation of consultancy support. Environment and Planning C: Government and Policy 18(4): 409-427.

Uyarra, E., Edler, J., Garcia-Estevez, J., Georghiou, L., \& Yeow, J. (2014). Barriers to innovation through public procurement: A supplier perspective. Technovation, 34(10), 631-645.

Uyarra, E. \& K. Flanagan (2010). Understanding the innovation impacts of public procurement. European Planning Studies 18(1): 123-143.

Van de Ven, A. H. (2007). Engaged scholarship: A guide for organizational and social research, Oxford University Press on Demand.

Van de Ven, A. H. \& P. E. Johnson (2006). Knowledge for theory and practice. Academy of management review 31(4): 802-821.

Vecchiato, R. \& C. Roveda (2014). Foresight for public procurement and regional innovation policy: The case of Lombardy. Research Policy 43(2): 438-450.

Wakolbinger, T., \& Cruz, J. M. (2011). Supply chain disruption risk management through strategic information acquisition and sharing and risk-sharing contracts. International Journal of Production Research, 49(13), 4063-4084.

Walker, H., \& Brammer, S. (2009). Sustainable procurement in the United Kingdom public sector. Supply Chain Management: An International Journal, 14(2), 128-137.

Walker, H., \& Jones, N. (2012). Sustainable supply chain management across the UK private sector. Supply Chain Management: An International Journal, 17(1), 15-28

Weick, K. E. (2001). Gapping the relevance bridge: Fashions meet fundamentals in management research. British Journal of Management 12: S71-S75.

Williamson, O. E. (2008). Outsourcing: transaction cost economics and supply chain management. Journal of supply chain management, 44(2), 5-16.

Wuttke, D. A., Blome, C., Foerstl, K., \& Henke, M. (2013). Managing the innovation adoption of supply chain finance-Empirical evidence from six European case studies. Journal of Business Logistics, 34(2), 148-166. 
Ya Ni, A. \& S. Bretschneider (2007). The Decision to Contract Out: A Study of Contracting for E-Government Services in State Governments. Public Administration Review 67(3): 531-544.

Yin, R. K. (2009). Case study research: Design and methods 4th ed. United States: Library of Congress Cataloguing-in-Publication Data.

Zeng, S. X., Xie, X. M., \& Tam, C. M. (2010). Relationship between cooperation networks and innovation performance of SMEs. Technovation, 30(3), 181-194.

Zhang, C., Viswanathan, S., \& Henke Jr, J. W. (2011). The boundary spanning capabilities of purchasing agents in buyer-supplier trust development. Journal of Operations Management, 29(4), 318-328.

Zheng, J., Roehrich, J. K., \& Lewis, M. A. (2008). The dynamics of contractual and relational governance: evidence from long-term public-private procurement arrangements. Journal of purchasing and supply management, 14(1), 43-54. 


\title{
APPENDIX 1, CASE STUDY TEMPLATE
}

\section{Case study template}

Case studies of 2,000-3,000 words should be prepared using the following format

\begin{abstract}
Up to 100 words summarizing how public procurement in your country is trying to engage small businesses in public-procurement contracts.
\end{abstract}

\section{Summary table}

\begin{tabular}{|l|l|}
\hline Case characteristic & Data \\
\hline $\begin{array}{l}\text { Type of public sector organization with } \\
\text { responsibility for small business policy }\end{array}$ & $\begin{array}{l}\text { e.g., central, state or local government } \\
\text { department attempting to engage small } \\
\text { businesses in public procurement }\end{array}$ \\
\hline Type of small business association & $\begin{array}{l}\text { e.g., number of members, geographic } \\
\text { coverage }\end{array}$ \\
\hline $\begin{array}{l}\text { Total annual public sector spend to be } \\
\text { influenced by policy }\end{array}$ & Please add a conversion to Euros \\
\hline $\begin{array}{l}\text { Policy target percentage of total spend } \\
\text { to be with small businesses }\end{array}$ & $\%$ \\
\hline $\begin{array}{l}\text { Percentage of total annual spend } \\
\text { currently with small businesses }\end{array}$ & $\%$ \\
\hline Key target users of policy & $\begin{array}{l}\text { e.g., all other government } \\
\text { departments/local councils/city hall }\end{array}$ \\
\hline $\begin{array}{l}\text { Current top three categories of spend } \\
\text { contracted to small businesses }\end{array}$ & 1. \\
\hline $\begin{array}{l}\text { Web address of guidance for small } \\
\text { businesses }\end{array}$ & 2. \\
\hline
\end{tabular}

\section{Part 1 - Context}

1. Definition of a small business in your country (turnover, number of employees)

2. Economic data of significance of the small business sector in your country - total and by industrial classification, etc., quoting percentage GDP, percentage employment, total number of small businesses

3. Description of the government body responsible for the design of policies, legislation/regulation and actions/initiatives encouraging small business engagement in public procurement; e.g., Office of Government Commerce in the U.K. 
4. Description of the main national/regional/local association of small businesses

\section{Part 2 - Perceptions of policy and policy performance gaps}

1. Perception of the government body responsible for the design of policies, legislation/regulation, and actions/initiatives encouraging small business engagement in public procurement of the quality of the policy and mechanisms used - quotes, comments from interviews and published reports, etc.

Get them to position their perception below and tick one box.

\begin{tabular}{|l|l|l|l|l|l|l|}
\hline Appalling & $\begin{array}{l}\text { Very } \\
\text { poor }\end{array}$ & Poor & Neutral & Okay & $\begin{array}{l}\text { Very } \\
\text { good }\end{array}$ & Excellent \\
\hline
\end{tabular}

Use multiple scores if more than one policy/mechanism is used.

2. Perception of the government body of effectiveness of the policy/mechanism in terms of small business engagement in public procurement - quotes, comments from interviews and published reports, etc.

Get them to position their perception below and tick one box.

\begin{tabular}{|l|l|l|l|l|l|l|}
\hline Appalling & $\begin{array}{l}\text { Very } \\
\text { poor }\end{array}$ & Poor & Neutral & Okay & $\begin{array}{l}\text { Very } \\
\text { good }\end{array}$ & Excellent \\
\hline
\end{tabular}

Use multiple scores if more than one policy/mechanism is used.

3. Perception of the main national/regional/local association of small businesses of the quality of policies, legislation/regulation, and actions/initiatives encouraging small business engagement in public procurement - quotes, comments from interviews and published reports, etc.

Get them to position their perception below and tick one box.

\begin{tabular}{|l|l|l|l|l|l|l|}
\hline Appalling & $\begin{array}{l}\text { Very } \\
\text { poor }\end{array}$ & Poor & Neutral & Okay & $\begin{array}{l}\text { Very } \\
\text { good }\end{array}$ & Excellent \\
\hline
\end{tabular}

Use multiple scores if more than one policy/mechanism is used.

4. Perception of the main national/regional/local association of small businesses of performance in terms of small business engagement in public procurement - quotes, comments from interviews and published reports, etc.

Get them to position their perception below and tick one box.

\begin{tabular}{|l|l|l|l|l|l|l|}
\hline Appalling & $\begin{array}{l}\text { Very } \\
\text { poor }\end{array}$ & Poor & Neutral & Okay & $\begin{array}{l}\text { Very } \\
\text { good }\end{array}$ & Excellent \\
\hline
\end{tabular}

Use multiple scores if more than one policy/ mechanism is used.

5. Type 1 mismatch between 1 and 3. This mismatch represents the gap between what government thinks its policies are to enable access to small businesses to government 
procurement contracts, and what small businesses think government policies are quotes, comments from interviews and published reports etc.

6. Type 2 mismatch between 2 and 4 . This mismatch represents the gap between what government thinks is the performance of its policies/practice to enable access to small businesses to government procurement contracts, and what small businesses think performance/practice is - quotes, comments from interviews and published reports, etc.

7. Type 3 mismatch between 3 and 4 . This mismatch represents the small businesses agenda, as it is the gap between what small businesses think is intended by the policy and what small businesses think happens in practice - quotes, comments from interviews and published reports, etc.

8. Type 4 mismatch between 1 and 2 . This mismatch represents the government agenda, as it is the gap between what the policymakers think is intended by the policy and what policymakers think happens in practice - quotes, comments from interviews and published reports, etc.

For more information on this mismatch tool, please see the following paper:

Harland, C.M. (1996). Supply Chain Management: Relationships, Chains and Networks. British Journal of Management, 7, Mar, S63-S81

\section{Part 3 - Examination of perceptions of causes of four types of policy and performance gaps}

Here, we propose that you discuss possible causes with the government body and the smallbusiness association, and document these two perspectives.

1. Government body perspective of causes

2. National/regional/local association of small businesses perspective of causes

Part 4 - Action plans to improve small business engagement in public procurement

Here, we propose that you compile a list of priorities of the top three actions that could be taken in the future to help close these policy/performance gaps. 


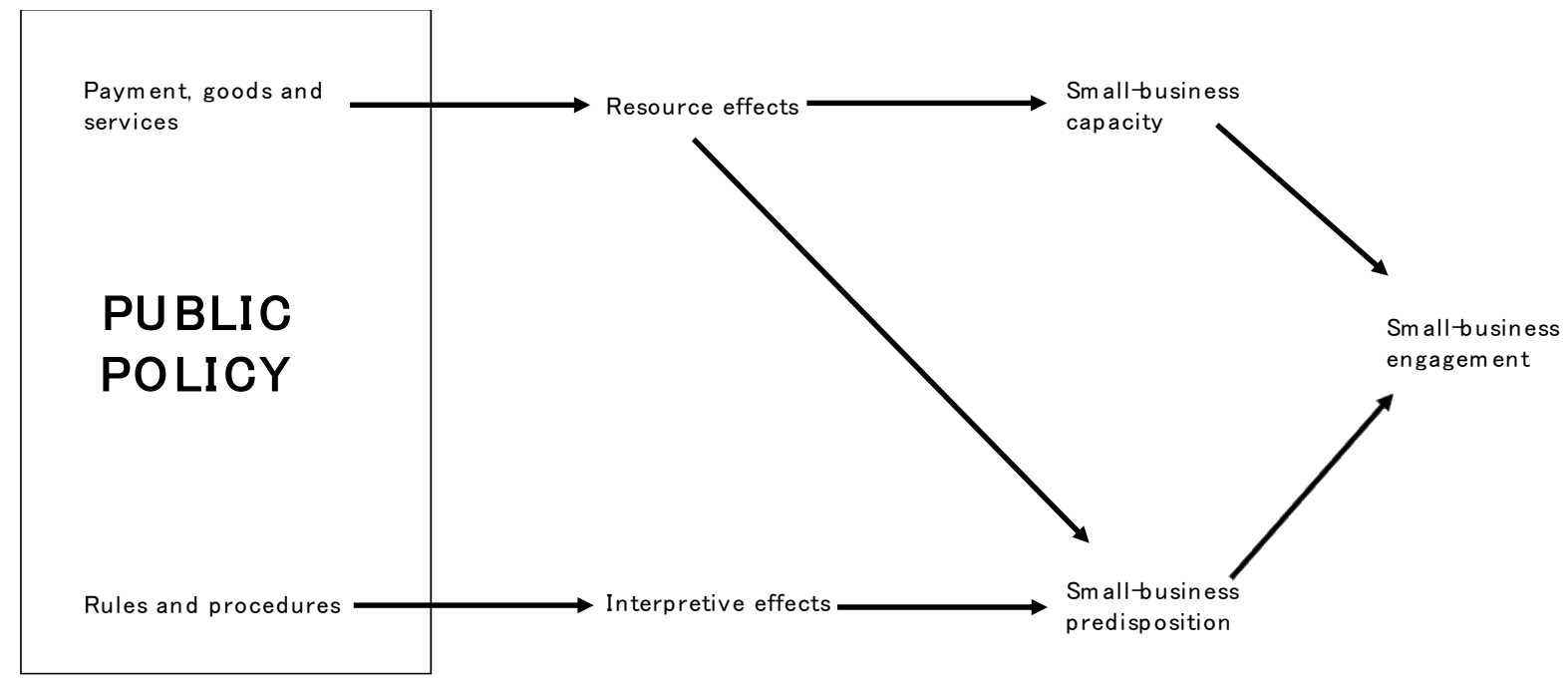

FIGURE 1

Policy Feedback Framework Adapted From (Mettler, 2002) 


\begin{tabular}{|c|c|}
\hline Mechanisms used & References \\
\hline $\begin{array}{l}\text { Greater publicity and transparency of how small businesses } \\
\text { can bid for public-procurement contracts }\end{array}$ & (Kidalov, 2013) \\
\hline $\begin{array}{l}\text { Specialist support for small businesses providing advice, } \\
\text { training, education, supervision and guidance, facilitation, } \\
\text { and technical assistance }\end{array}$ & $\begin{array}{l}\text { (Turok \& Raco, 2000, } \\
\text { McKevitt \& Davis } \\
\text { 2015) }\end{array}$ \\
\hline Prompt payments to small-business suppliers & (MacManus, 1991) \\
\hline $\begin{array}{l}\text { Targeted economic development in small-business } \\
\text { dominated areas, creating demand for small-business } \\
\text { products and services }\end{array}$ & $\begin{array}{l}\text { (Aschhoff \& Sofka } \\
\text { 2009) }\end{array}$ \\
\hline Provision of financial assistance to small businesses & $\begin{array}{l}\text { (Su-Yol \& Klassen } \\
2008)\end{array}$ \\
\hline $\begin{array}{l}\text { Decreased administration burden for small businesses } \\
\text { bidding for public-procurement contracts through } \\
\text { simplification of procedures }\end{array}$ & (Loader, 2011) \\
\hline Smaller contracts and "bundling" & $\begin{array}{l}\text { (Hartmann et al., } \\
\text { 2014) }\end{array}$ \\
\hline $\begin{array}{l}\text { Set-asides for small businesses (where portions of public- } \\
\text { procurement spending is reserved for small businesses) }\end{array}$ & $\begin{array}{l}\text { (Denes, 1997, } \\
\text { Nakabayashi, 2013) }\end{array}$ \\
\hline "Buy local" public-procurement policy & $\begin{array}{l}\text { (Walker \& Brammer } \\
\text { 2009) }\end{array}$ \\
\hline $\begin{array}{l}\text { Government mandate across government departments to } \\
\text { assist small businesses in gaining public-procurement } \\
\text { contracts }\end{array}$ & $\begin{array}{l}\text { (Georghiou et al., } \\
\text { 2014) }\end{array}$ \\
\hline $\begin{array}{l}\text { Offsets, where suppliers commit to provide additional goods } \\
\text { or services to gain public-procurement contracts) }\end{array}$ & $\begin{array}{l}\text { (Broecker \& Beraldi } \\
\text { 2017) }\end{array}$ \\
\hline $\begin{array}{l}\text { Use of e-procurement to improve small-business } \\
\text { engagement }\end{array}$ & $\begin{array}{l}\text { (Albano et al., 2015, } \\
\text { Fernandes \& Vieira } \\
\text { 2015) }\end{array}$ \\
\hline $\begin{array}{l}\text { Monitoring and measuring small-business engagement with } \\
\text { public procurement }\end{array}$ & $\begin{array}{l}\text { (Georghiou et al., } \\
\text { 2014) }\end{array}$ \\
\hline Dedicated small-business website & $\begin{array}{l}\text { (Kidalov \& Snider, } \\
\text { 2011) }\end{array}$ \\
\hline Selected evaluation criteria favouring small businesses & $\begin{array}{l}\text { (Maréchal \& Morand, } \\
\text { 2012) }\end{array}$ \\
\hline $\begin{array}{l}\text { New standards giving more flexibility and preferential } \\
\text { treatment to small businesses }\end{array}$ & (Marion, 2007) \\
\hline Online help facility for small businesses & (Booth, 2011) \\
\hline
\end{tabular}

\section{TABLE 1}

Research evidence of mechanisms used in public procurement to engage small businesses 


\begin{tabular}{|l|l|c|l|c|l|}
\hline Case & Country & \multicolumn{5}{|l|}{ Case study coproduction team } \\
\hline & $\begin{array}{l}\text { Senior } \\
\text { academic }\end{array}$ & $\begin{array}{l}\text { Junior } \\
\text { academic }\end{array}$ & $\begin{array}{l}\text { Senior } \\
\text { professional }\end{array}$ & $\begin{array}{l}\text { Junior } \\
\text { professional }\end{array}$ \\
\hline A & Austria & 1 & & 1 & \\
\hline B & China & 2 & 3 & 1 & 2 \\
\hline C & $\begin{array}{l}\text { South } \\
\text { Africa }\end{array}$ & 1 & & 2 & \\
\hline D & USA & 1 & & 3 & \\
\hline E & Australia & 1 & 1 & 2 & \\
\hline F & Canada & 1 & & 1 & \\
\hline G & Norway & 1 & & 1 & \\
\hline H & UK & 1 & & 1 & \\
\hline I & Belgium & 1 & & 1 & \\
\hline J & Italy & 1 & & 2 & \\
\hline K & Hungary & 1 & & 2 & \\
\hline L & Mongolia & & & 2 & \\
\hline M & Uganda & 1 & & 2 & \\
\hline
\end{tabular}

TABLE 2

Case Study Coproduction Teams 


\begin{tabular}{|c|c|c|c|c|c|c|c|c|c|c|c|c|c|c|}
\hline $\begin{array}{l}\text { Case } \\
\text { study }\end{array}$ & $\begin{array}{l}\text { Mechanis } \\
\text { ms used }\end{array}$ & 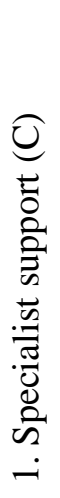 & 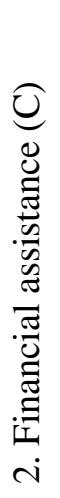 & 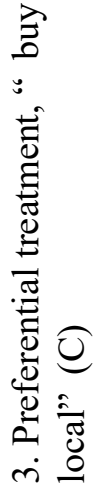 & 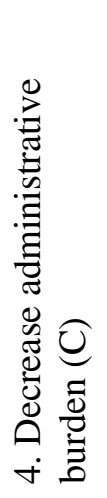 & $\begin{array}{l}0 \\
0 \\
0 \\
0 \\
0 \\
0 \\
0 \\
0 \\
0 \\
0 \\
0 \\
0 \\
0 \\
0\end{array}$ & 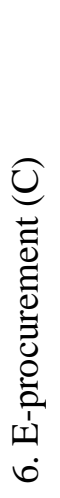 & 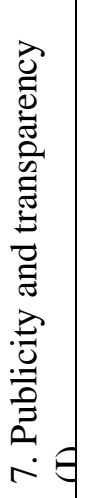 & 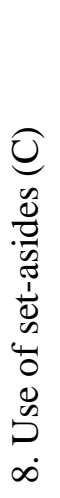 & 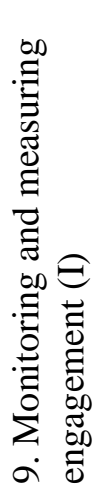 & 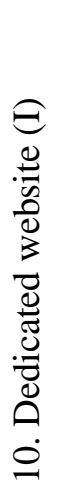 & 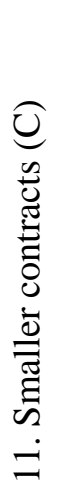 & 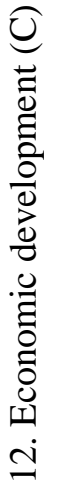 & 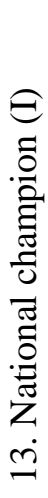 \\
\hline Austria & $6(5 \mathrm{C}, 1 \mathrm{I})$ & 1 & 1 & 1 & 1 & & & 1 & & & & 1 & & \\
\hline China & $11(5 \mathrm{C}, 6 \mathrm{I})$ & 1 & 1 & 1 & & & 1 & 1 & & & 1 & & 1 & \\
\hline $\begin{array}{l}\text { South } \\
\text { Africa }\end{array}$ & $6(6 C)$ & 1 & 1 & & 1 & 1 & & & 1 & & & & 1 & \\
\hline USA & $5(3 \mathrm{C}, 2 \mathrm{I})$ & 1 & 1 & & & & & & 1 & 1 & 1 & & & \\
\hline Australia & $5(3 \mathrm{C}, 2 \mathrm{I})$ & 1 & & 1 & & 1 & & & & & 1 & & & \\
\hline Canada & $5(1 \mathrm{C}, 4 \mathrm{I})$ & 1 & & & & & & 1 & & 1 & & & & \\
\hline Norway & $4(4 \mathrm{C})$ & 1 & & & 1 & & 1 & & & & & 1 & & \\
\hline UK & $5(1 \mathrm{C}, 4 \mathrm{I})$ & & & & & 1 & & 1 & & 1 & & & & 1 \\
\hline Belgium & 0 & & & & & & & & & & & & & \\
\hline Italy & $2(2 \mathrm{C})$ & 1 & & & & & 1 & & & & & & & \\
\hline Hungary & $3(3 C)$ & & 1 & & & 1 & & & & & & 1 & & \\
\hline Mongolia & $2(2 C)$ & & & 1 & 1 & & & & & & & & & \\
\hline Uganda & $6(6 C)$ & 1 & 1 & 1 & 1 & & 1 & & 1 & & & & & \\
\hline Totals & & 9 & 6 & 5 & 5 & 4 & 4 & 4 & 3 & 3 & 3 & 3 & 2 & 1 \\
\hline
\end{tabular}

TABLE 3

Mechanisms Used In Each Case 


\begin{tabular}{|c|c|c|}
\hline Case study & $\begin{array}{c}\text { Number of } \\
\text { mechanisms used to } \\
\text { engage small } \\
\text { businesses }\end{array}$ & $\begin{array}{c}\text { Cluster } \\
\text { number }\end{array}$ \\
\hline J-Italy & $2 \mathrm{C}$ & 1 \\
K-Hungary & $3 \mathrm{C}$ & 1 \\
L-Mongolia & $2 \mathrm{C}$ & 1 \\
\hline B-China & $11(5 \mathrm{C}, 6 \mathrm{I})$ & 2 \\
\hline I-Belgium & 0 & 3 \\
\hline A-Austria & $6(5 \mathrm{C}, 1 \mathrm{I})$ & 4 \\
C-South Africa & $6(6 \mathrm{C})$ & 4 \\
D=USA & $5(3 \mathrm{C}, 2 \mathrm{I})$ & 4 \\
E-Australia & $5(3 \mathrm{C}, 2 \mathrm{I})$ & 4 \\
F-UK & $5(1 \mathrm{C}, 4 \mathrm{I})$ & 4 \\
G-Norway & $4(4 \mathrm{C})$ & 4 \\
H-UK & $5(1 \mathrm{C}, 4 \mathrm{I})$ & 4 \\
M-Uganda & $6(6 \mathrm{C})$ & 4 \\
\hline
\end{tabular}

TABLE 4

Clusters Of Cases 


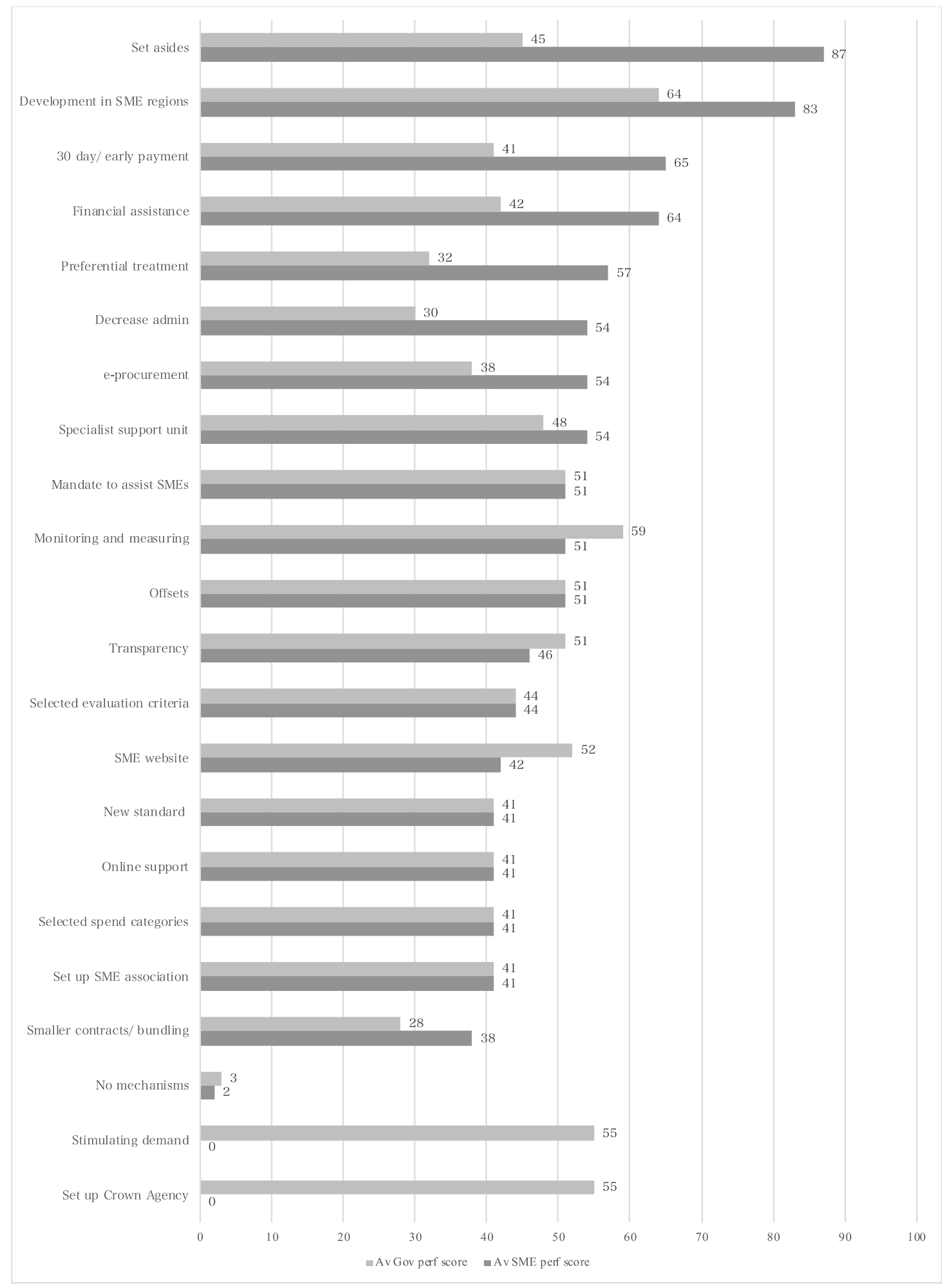

FIGURE 2

Public Procurement And Small-Business Perceptions Of Mechanism Effectiveness 


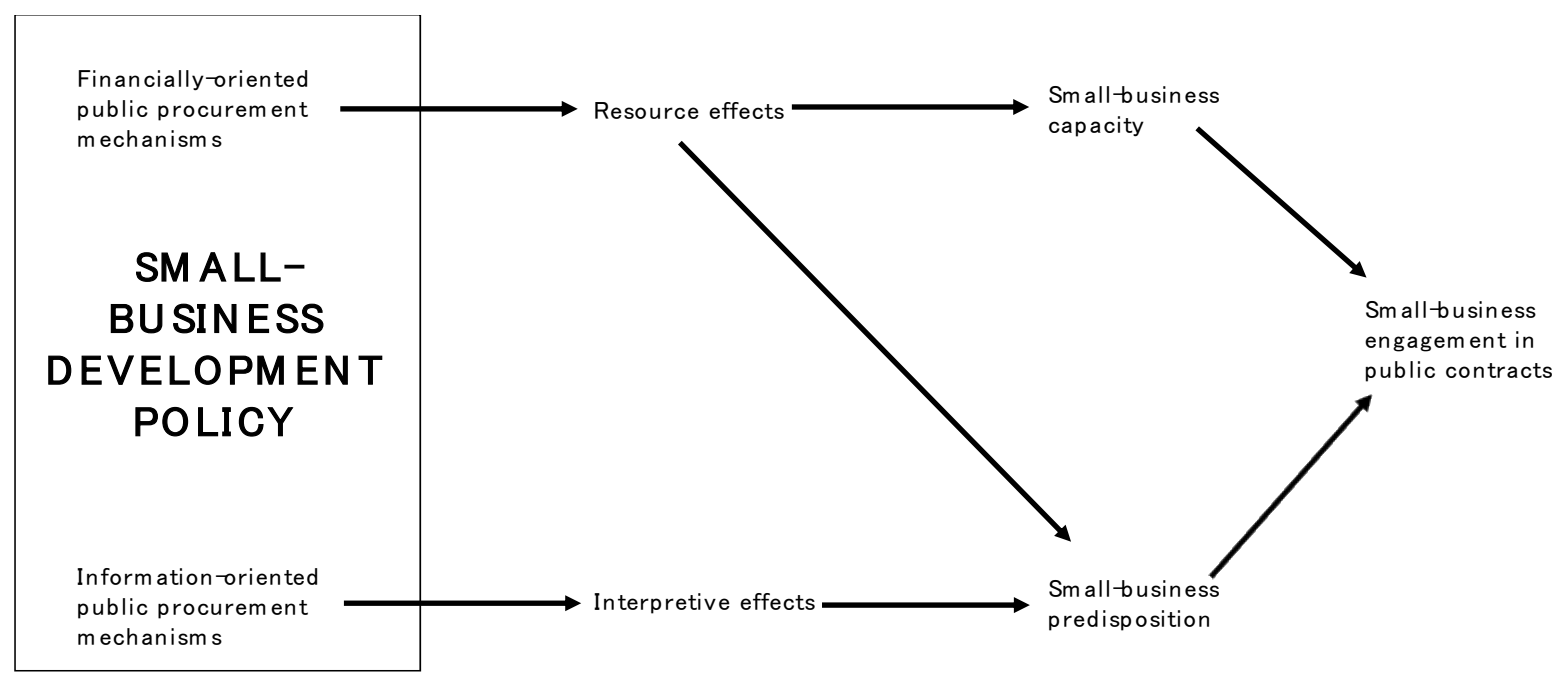

FIGURE 3

Small-Business Development Policy Feedback Framework (Adapted From Mettler, 2002) 